\title{
Zhang Peili's Flying Machine and the ends of painting in Chinese contemporary art
}

\section{Olivier Krischer}

Zhang Peili's work is commonly seen as a steady movement from painting to video. Zhang completed what is known as the first video work in China, in 1988, and exhibited the first Chinese video art in 1991, after which he consistently worked with more complex video installations. Yet the re-emergence of the painting Flying Machine (1994) - one of Zhang's last few canvases, and thought to be lost-reminds us that even artists such as Zhang continued to grapple with their academy training, in his case in oil painting, not simply as a technique but as a 'language' (yuyan 语言).

In 1995, during what became a ten-month sojourn in New York, Zhang Peili wrote: 'The role of art is that of eliminating obstacles, and this is also its meaning. Therefore, my starting point is everyday life and normal experience. I wish for my work to stand between art and life, or, in other words, on an indefinite border.'1 Flying Machine marks the culmination of Zhang's search for an expression of this intermediate, indeterminate position in painting, completed while he was also producing some of his first seminal videos and installations. 
Here I wish to consider how Zhang, across different media, explored common issues and themes, such as the perennial tension between the sign and the signified, as well as notions of iteration, copying, reproduction and especially reception, which I think are rooted in Zhang's earlier practice. Although Zhang came to focus on the possibilities of video installation from the mid-1990s, this essay seeks to retrieve the role of painting in the development of Zhang's finely wrought artistic 'language'. By doing so, it is also an exercise in considering the artist distinct from the narratives to which he has been assigned.

\section{Art and life}

First, it is necessary to consider the longer development of Zhang's painting practice. Through a series of group activities, exhibitions and individual works between his graduation in 1984 and his initial move away from painting in 1987, the concept of 'language' became a central concern in Zhang's practice. The Zhejiang Creation Society was a loosely affiliated group of artists, including Zhang, who had gathered in frustration at the regressive conservatism of the Sixth National Art Exhibition, of 1984. Without a manifesto or shared aesthetic mission, they originally gathered in part to access funding with which to organise a different sort of exhibition project. The result was the '85 New Space exhibition, widely considered groundbreaking. Zhang and other participants nevertheless immediately felt the need to bring art more directly into public space, to 'immerse' art into daily life, leading to the formation of the Pond Society the following year, a group that staged ephemeral public art installations and some performances, in Hangzhou. ${ }^{2}$ It was also in 1986 that Zhang began the seminal $X$ ? series of glove paintings, in which he sought to free painting from the 'burden' of narrative. Both his individual works and those of the Pond Society were critical responses to the emerging formalisation of new art under the banner of the '85 New Wave.

The subjects of Zhang's early paintings often seem sublimated and generalised from what begin as more specific, personal references-such as his brother's saxophone in the Jazz series, or the surgical gloves of $X ?,{ }^{3}$ which recall the medical environment around which he grew up (one shaped by his parents' work in a hospital and his significant experience of illness during his childhood). The '85 New Space paintings presented a realism that reveals as it conceals; in these, seeing is not knowing. While labelled 'cool', they are not merely boring or lifeless; they seem to posses the anonymity, ambivalence and uncanny isolation 
of the urban crowd. The stark shadows smooth out the bodies and faces, making them less personal, more generic. Sometimes the figures are faceless, unwilling or unable to return the viewer's gaze (see Swimmers in the Water, p. 64). ${ }^{4}$

Much of this painting derived from the critical approach Zhang, Geng Jianyi and their circle had developed to socialist realism, not simply in terms of a style but rather as a 'language', in which 'narrativism' and historical responsibility 'cripple painting's inherent value'. ${ }^{5}$ Their critique extended from its roots in the latenineteenth-century Russian 'Wanderers' school (Передви́жники, Peredvizhniki), through to new trends of Scar art and rustic realism, which Zhang and his peers considered not fundamentally different in terms of their 'language'. In Luo Zhongli's Father (1980), for example, while it appeared radical to bring a 'real' peasant into the conservative lexicon of China's academy oil painting, the painting did not shift the relationship between art and society. Such painting was quickly absorbed by the establishment, on political and technical merit, providing a new model. ${ }^{6}$

Such new trends in oil painting also invested in technical virtuosity, further distancing artists, as elite technicians-and art, as a technology-from everyday life. Zhang and his peers were wary of technique as well as authorial subjectivity, both hallmarks of academy training. ${ }^{7}$ For the $X$ ? series, Zhang had initially planned to paint one hundred versions of the same glove painting, 'using repetition to eliminate the difference between each work'. ${ }^{8}$ In the twenty or so glove paintings completed, he deliberately used subdued tones, and painted in a studied manner, as though anyone with training might achieve an equivalent result. Importantly, the paintings are not identical, yet their differences are not significant enough to make them discrete objects of appreciation or analysis. They achieve a sameness, blurring into one another visually and conceptually, collectively becoming 'the glove paintings'. However, they remain realistic rather than tending to formal abstraction. Hence, in the glove paintings, any narrative (for example, memory) resides almost entirely with the viewer (see $X$ ?, p. 70). ${ }^{9}$

For Zhang, the $X$ ? series already marked a departure from his painting practice, since these were conceived and executed as procedural, scripted actions, reflecting the kind of exploration that would find a home in the Pond Society (Chi she, also Pool Society), too. The textual works Program of Asking for Permission before Executing: About $X$ ? (1987), comprising a handwritten fourteen-page plan, and Art Plan No. 2 (1987), a mimeographed text piece, go further by removing the 'visual' altogether. This conceptualised relationship between 
the artist, the audience, the medium and the creative space in which the work happens was influenced by Kafka but especially by the Polish dramaturge Jerzy Grotowski's Towards a Poor Theatre (1968). ${ }^{10}$ As one contemporary review observed, 'For Grotowski the theater is not simply a place where plays are performed or where another facet of our culture can be safely viewed: [it] is a Pandora's box which must be opened because the ritual of discovery is the only meaningful one for man." 11

In the idealism of the 1980s, much art remained transcendent. Many aspired to 'purity', yet there were significant differences in theoretical approach and practice. For example, the quasi-mystical scenes of the Northern Art Group, led by Wang Guangyi, were aligned with some painting by Zhang and other Hangzhou colleagues as 'rational painting'. At the time, the work of the Northern Art Group aspired to be a kind of 'sublime' convergence of world traditions, manifest in the post-industrial landscapes of northeast China, solemnly depicted in simple, dark-grey tones. The conceptual explorations of the Pond Society and Zhang's closely related individual practice between 1987 and 1988, were a critical response to the historicising and packaging of new art as a 'movement'.

\section{Painting after 1989}

If the China/Avant-garde exhibition in February 1989 presented a contested yet definitive conclusion to a lingering sense of collective purpose, the violent suppression of the June protest movement, and particularly the subsequent nationwide pressure in the cultural sector ${ }^{12}$, made the art of the 1980s appear-according to Zhangfeeble and esoteric, even naive. ${ }^{13}$

In the wake of 1989, Zhang felt art was like 'an itch you can't scratch'. He wanted his work to be more 'concrete', but not necessarily 'neutral' or 'positive' about reality in the way of classic American pop art. Zhang tried to create a 'prompt' (tishi 提示) rather than pass judgement: ${ }^{14}$ 'At that time, I felt like my previous schematic works, plans and videos as well, were a bit metaphysical, a bit too distant from reality. So from then, and for a period, I kind of used my original painting practice to return to reality.' ${ }^{15}$

In fact, on 7 June 1989, Zhang and Geng Jianyi produced two huge painted banners, $3 \times 7$ metres each, based on international press photographs of the victims in Beijing. They paraded the banners through downtown Hangzhou before hanging them from a pedestrian bridge. For Zhang, however, he says they did not consider this an artwork. ${ }^{16}$ 
Zhang's first artwork that year was a mixed-media painting titled Chinese Bodybuilding: Elegance of 1989 (1989, see p. 70), which looks radically different from those in his $X$ ? series. Described by Zhang as 'painted flat, like painted advertisements', the 1989 work has a collage effect, incorporating stamps, old ration coupons (a fast-disappearing symbol of the socialist economy) and labels from imported cosmetics, composed in an intentionally straightforward fashion. The dominant image is of a Chinese female bodybuilding champion, with fashionably permed short hair, raising a trophy as she flashes her white teeth-her competition weight 'stamped' on the lower right of the work. Above and below her, the head of a Cultural Revolution opera singer is repeated in rows. In contrast, an official-looking seven-character phrase down the left side reads, 'When liberated, don't forget the Communist Party' (fanshen buwang gongchandang 翻身不忘共产党). Any adult would have been able to silently complete this once ubiquitous slogan: 'When prosperous, don't forget Chairman Mao' (xingfu buwang Mao zhuxi 幸福不忘毛主席).

Zhang has acknowledged the apparent relationship of this work to political popas the genre would soon be described by critic and curator Li Xianting-but Zhang aligns it instead with the more self-reflexive pop of Richard Hamilton in the 1950s, which stemmed from collage rather than painting. ${ }^{17}$ If we compare Chinese Bodybuilding with Wang Guangyi's Great Criticism series, often seen as the classic example of political pop, Wang's paintings, combining 'model' Cultural Revolution graphics with those of Western commercial brands, present themselves as well-designed posters of consumer mass culture supplanting the hegemony of politics during the Cultural Revolution. ${ }^{18}$ On the other hand, Zhang's work, while similarly bright, brash and textual, remains more circumspect. His 'pop' is domestic; the juxtapositions, while legible as political and popular, do not combine to depict an integrated picture of 'socialism' or 'globalisation', or even 'China'. ${ }^{19}$

Chinese Bodybuilding: Elegance of 1989 (1989), the first in a series of works featuring bodybuilders and newsreaders, juxtaposes disparate elements of popular culture and social history, which, while appearing more directly symbolic than his earlier work, are difficult to restrict to specific, shared meanings. The glove in the $X$ ? series was a suggestive 'intermediary object', but the bodybuilders in Zhang's series embody a kind of uncertain state. Zhang was interested in the tension between a state of health and one of excess, of such conditioned bodies as both beautiful and gaudy. ${ }^{20}$ In the context of 1980 s China, 

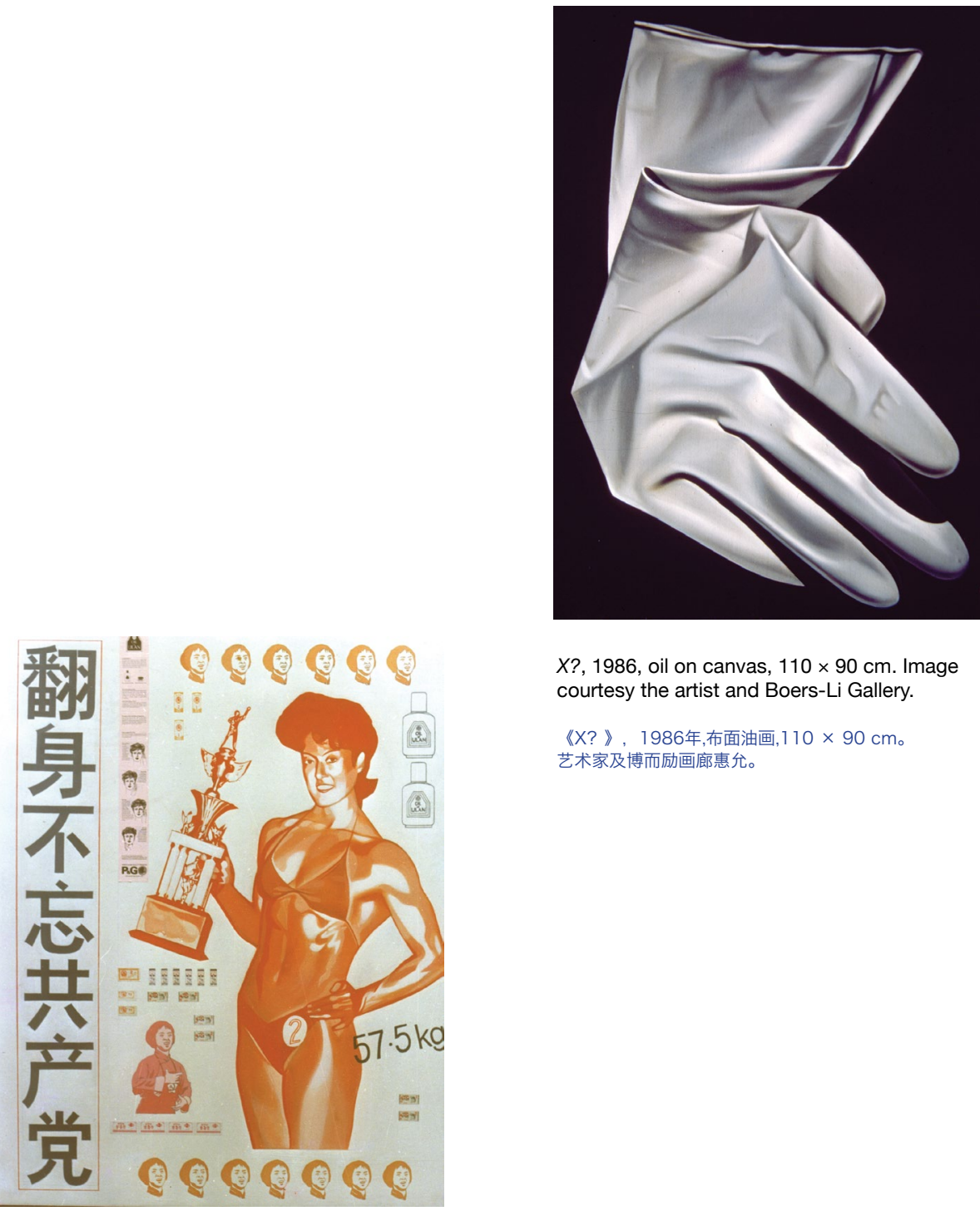

$X$ ?, 1986 , oil on canvas, $110 \times 90 \mathrm{~cm}$. Image courtesy the artist and Boers-Li Gallery.

《X?》, 1986年,布面油画, $110 \times 90 \mathrm{~cm}$ 。 艺术家及博而励画廊惠允。

Chinese Bodybuilding: Elegance of 1989, 1989, oil and mixed media on canvas, $100 \times 80 \mathrm{~cm}$. Image courtesy the artist and Boers-Li Gallery.

《中国健美一1 1989 的风韵》, 1989年, 布面油画及混合媒体, $100 \times 80 \mathrm{~cm}$ 。 艺术家及博而励画廊惠允。 
bodybuilding intersected with the development of 'lifestyle' and the new media spectacle of television. As bottom-up popular culture, bodybuilding was distinct from both government conservatism and intellectual 'high culture fever'. ${ }^{21}$

Bodybuilding had been banned in communist China, because of attitudes and regulations regarding 'nudity', especially for women, and probably because it was not an Olympic sport; it was about self-image and personal ambition rather than national achievement. ${ }^{22}$ Although the ban was lifted in 1983, women were obliged to compete in demure one-piece swimsuits until 1986, when authorities allowed bikinis for the championships, which were aptly held in the newly developing special economic zone of Shenzhen. ${ }^{23}$ While the participants were all amateurs, the televised spectacle-which featured pop music and roving spotlights, as well as running commentary on each contestant's occupation and home province-was clearly a homegrown combination of commercial opportunity and deregulation, reflecting the media's new commercial imperatives, a shift in public taste, and the potential for a market to replace or extend state patronage. ${ }^{24}$

Zhang's work is known for avoiding cultural symbolism. For Zhang, however, there is an important difference between contingent 'elements' that are lived and 'symbols' that package identity for utilitarian or strategic ends: 'Symbols can be used in a utilitarian way, but they can also be used in a destructive or disruptive way, what one might call a creative way. These two methods are completely different; only one of them will convey new understandings. But it's problematic when symbols are used simply as a strategy for expressing identity. ... I'm opposed to a singular cultural psychology, a fixed mode of observation or understanding.' 25

The visual assemblage in Chinese Bodybuilding: Elegance of 1989 is not of new parts but of new relationships. The arrangement of these elements, in layered juxtaposition, to convey some new understanding, recalls the notion of collage and montage that Walter Benjamin planned to use to structure his unfinished opus, Das Passagen-Werk [The Arcades Project]. Montage, he wrote, 'interrupts the context into which it is inserted' and thus 'counters illusion'. ${ }^{26}$ Defending his approach, he insisted, 'I have nothing to say. Only to show.' ${ }^{27}$

The elements Zhang used derive from media publications, and suggest the relationship of painting to photography, or, rather, to reprographic images, a subject rarely discussed in the discourse around Chinese contemporary art. In a catalogue essay for the photorealist painter Chen Danqing, Wu Hung has traced 
the practice of painting from photographs as a 'primary feature' of Chinese oil painting since the Cultural Revolution. ${ }^{28}$ The use of photos related not to a lack of real subjects but to the dilemma of 'authentication and idealisation'. Massive numbers of 'typical' images were copied and circulated through newspapers, magazines and movies; and this process gave photographic images a historical, archival quality. Paintings based on photographic images could thus share in this consensual 'truth', potentially saving the artist from accusations of errant individualism. Artists consequently began collecting magazine and news clippings, even competing to identify iconic images. ${ }^{29}$ Pang Laikwan has argued that this culture of models and copying was part of a programme of 'social mimesis' with roots in the early 1940 s yet which reached its apex during the Cultural Revolution. ${ }^{30}$

Rather than being 'model' characters, all of the figures in Zhang's paintings from 1989 to 1994 strategically foreground their origin as printed media by retaining cropped edges, such as the bodybuilder's cropped legs in Chinese Bodybuilding: Elegance of 1989, or the duplicated newsreader in the diptych The Good Life Comes from TV (1991, see p. 77). ${ }^{31}$ This is likewise a feature of the wedding-andsoldier series Zhang developed during his Art Omi residency in New York in 1992 (his first trip overseas). ${ }^{32}$ The triptych Water: Standard Pronunciation of 1989 (1990), which anticipates his 1991 video Water: Standard Version from the Cihai Dictionary (1991), similarly depicts the iterated 'frame' of a flickering television screen when photographed. ${ }^{33}$

Although the $X$ ? series was also painted from photographs, the gloves sensuously bend and hang around the contours of absent objects or surfaces. After 1989, however, Zhang's paintings highlight their status as images of images; without any pretence of spatial depth they borrow less from the theatre than from the television screen. Here the power or authority of media (rather than 'the media') itself becomes a key concern, with Zhang attempting to leverage the plastic qualities of painting -its ability to manipulate size, form, density, colour and printing -in order to recast these elements at a critical distance between their source and the audience.

The 'reality' to which Zhang returned through these paintings is not smooth, nor is it whole; it is simultaneously multiplying and disintegrating across uncertain images, translucent layers, screen-printed repetitions and montage arrangements. The edges of such works are explicit, undeniable, indeed integral to their 'language', formally and conceptually. 
In the diptych The Good Life Comes from TV (1991) the news reader Luo Jing (who, like Xing Zhibin, was a well-known anchor on the daily evening news program Xinwen lianbo 新闻联播, lit. 'news broadcast') is painted on two canvases, as though a repeated screen-print, yet each instance is subtly distinct. $\mathrm{He}$ and all other elements do not reach the edge of the canvas, emphasizing their graphic two-dimensionality, reinforced by the stark monochrome cropped images layered in different densities on top. The composition of each canvas is the same. The same effect, of apparent repetition yet actual difference, is repeated with the two lower images on each canvas, reinforced by the slightly different sequential numbers at the bottom of each: 44-722 and 44-723.

The copying (or iteration) and transformation of media, and the tension between repetition and distinction, featured in different ways across each of the works in Zhang's significant first solo exhibition, at Galerie du Rond-Point, in Paris, in early 1993. ${ }^{34}$ In the photographic installation Copied Consecutively 25 Times (1993), for example, Zhang took an image of a smiling 'peasant' (from a 1970s issue of China Pictorial) to Paris, where he then had a photographer make twenty-five consecutive copies, such that the black-and-white image becomes increasingly grainy, mottled and abstract. The work was installed as a single line, illustrating the process from the legible original to the final 'copy'.

In the same exhibition, Zhang presented Assignment No. 1 (1992) for the first time, a six-channel, twelve-monitor video installation showing, close up, a finger being pierced to take a blood sample. (The video was separated and manipulated into different colour channels in post-production. $)^{35}$ Even the video work Document on Hygiene No. 3 (1991) was installed not as a multi-channel work but as five copies derived consecutively from the original tape, with each slightly more degraded iteration shown on a separate monitor. ${ }^{36}$

For this exhibition, Zhang also realised a new installation that similarly probes the 'indefinite border' between material and identity. The mixed-media work Feimaipin 非卖品 (lit. 'Unsaleable goods', or 'Not for sale') (1993, see p. 77), comprised a series of display cases, in which were exhibited similarly shaped mounds of fine powder. While the original materials were diverse, they were rendered equivalent by being finely ground (except for the fur and hair) -in other words, recalls Zhang, reduced to their smallest possible parts while remaining tangible. The materials were all basic, with a range of everyday roles, and largely universal, including flour, salt, milk powder, animal fur and skin, human hair, bone, plaster, iron dust, coal slack, calcimine, and lime. ${ }^{37}$ In another solo exhibition 
in Paris, later that year, Zhang completed a related installation, this time using plaster to make a mould of square sections of a gallery basement space, from which he used wax to make casts, stacking plaster (the negative) and wax (the 'print', or positive) on the section of the floor that had been 'copied'. ${ }^{38}$

\section{A flying machine}

These diverse works enact a process that has been described in Zhang's later media installations as 'activating' the viewer, whereby 'the real interactivity that takes place is not just between the viewer and the artwork, but the viewer and him or herself'. ${ }^{39}$ Such a process of both providing and revealing the viewer's contingent position has developed in Zhang's work since at least the $X$ ? series of paintings, and functions similarly in Zhang's Flying Machine. In this painting, through the use of scale, perspective, texture and a simplified colour scheme, Zhang sought not to appropriate the symbolic force of an image but rather to neutralise or release it, to open the image to other interpretations.

In Flying Machine, a sombre form is suspended on a wide stretch of smooth blue (see p. 78). We recognise the nose and tail, the rotating blades, yet the proximity, the angle is that of the camera eye. The object is skewed, flattened in a moment offtime, but it is no longer a snapshot. There is no narrative detail beyond its outline, yet this indeterminate border - a concept, really-separating what it is from what it is not. We are not intended to recognise a make or model that might reveal the history, function, politics or allegiance of this potent object. All of this is flattened, smoothed, aggregated. The silhouette is formed by a final, carefully painted layer of thick blue paint that masks the underlying charcoal, dripped grey and ruddy brown, with translucent strokes of bluish white. ${ }^{40}$

The masked subject and gestural layering suggest a formal relationship to works such as the triptych Chinese Bodybuilding: Syntax of 1989 (1991, see p. 78), which depicts two male bodybuilders, a mimeograph machine and the phrase 'internal circulation' (neibu faxing 内部发行), indicating materials restricted to specialist use in specific domains but not fit for public consumption. ${ }^{41}$ It is also around this period, between 1991 and 1992, that military imagery begins to appear in some of Zhang's paintings, such as the large-scale five-panel Rose Red and Grey (1992), made for the 1993 Venice Biennale and possibly inspired by imagery from the Gulf War (1990-91) and the Bosnian War (1992-95). ${ }^{42}$ 
The Working Manual includes two helicopter works, presented as Zhang's last two paintings. But Conner retains another, previously undocumented work, which sheds light on the painting now in Canberra, and the direction of this series. ${ }^{43}$ This 'black' Flying Machine (see p. 82) is a brooding painting of sooty tones, from under which a hint of yellow glows. Here Zhang has used the same helicopter silhouette as in the 'blue' Flying Machine, diminishing the signified object through its repetition as a motif. But whereas the textural layers are muted by the smooth blue outline in the Canberra Flying Machine, in Conner's work the dark paint simmers unfettered, toying with a formal abstraction and objecthood that is punctuated by long scratches made directly onto the painted canvas. Considered together, it seems as though Zhang was searching for a painted idiom between representation and abstraction, between representation and form.

\section{Entering the world}

One of the ironic outcomes of the severe response to 1989 was the swiftness with which the government set about developing the economy; and most people, across all sectors, eagerly followed. Already in 1990, China's first stock exchange had been established in Shanghai, and the following year saw the first auction of Chinese oil painting in Hong Kong. But it was in 1992, during a Chinese New Year visit to southern China, that Deng Xiaoping made a series of statements advocating the development of a 'socialist market economy', which led to the establishment of the first special economic zones. Many leading artists and critics became entrepreneurial, seeing in the market an alternative to state validation or sponsorship. In 1992, the 'Guangzhou - The First 1990s Biennial Art Fair', as it was called in English, was organised with private sponsorship, as a large-scale commercial exhibition, also offering over twenty cash prizes. It was novel yet ultimately revealed the organisers' idealism and inexperience, when expenses exceeded earnings due to overly optimistic revenue predictions. ${ }^{43}$

In this same period, Zhang, like a number of leading artists, soon had opportunities to travel and exhibit abroad. In this context, by late 1994 Zhang had decisively put painting aside, feeling that the medium had become too estranged from 'life'; that he had been unable to cast off his art school training. In the 1980s, Zhang and others had sought to expand the language of painting, but in significant ways this had been accommodated, even co-opted, into the narrative of modernisation and national redemption, through economic and cultural development. As China 'entered the world', particularly from 1993, there was a sense that Chinese art, too, was regaining its rightful global prominence. However, the image of Chinese 
art was also being conditioned by increasingly influential curatorial and art-critical discourses, exemplified by the dominance of painting, and particularly works in the styles dubbed political pop and cynical realism, through exhibitions such as the 1993 Venice Biennale and China's New Art Post-1989 the same year. ${ }^{44}$

However, the developing critique of this influence was also apt to take on a combative cultural chauvinism. While Zhang pointedly cultivated a 'formal neutrality' 45 in his work, he addressed this tendency in his 1996 text 'At War with the West?', written for a group exhibition in Munich. ${ }^{46}$ Here Zhang called out the tendency of younger critics in China to frame art as though it were an Olympic competition, conflating artistic achievement and even aesthetics with questions of national ambition to overcome the West. ${ }^{47}$ Zhang's turns away from painting as a medium (both around 1986 and again from 1994) may then be seen as a continued refusal to content oneself with the easy (and lucrative) identity politics of either the state or the global art market, cultivating instead a third space-that space in which Flying Machine still hovers, on an 'indefinite border'. ${ }^{48}$ 


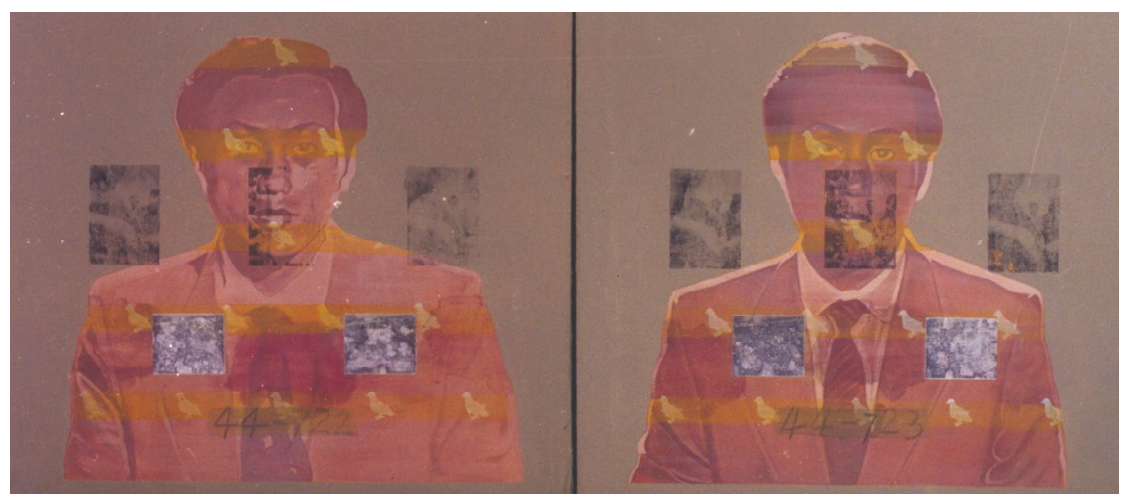

The Good Life Comes from TV, 1991, oil on canvas, diptych, $100 \times 100 \mathrm{~cm}$ each. Image courtesy the artist and Boers-Li Gallery.

《幸福生活来自TV》, 1997年, 布面油画, 双联画, 每幅100 × $100 \mathrm{~cm}$ 。艺术家及博而励画廊惠允。

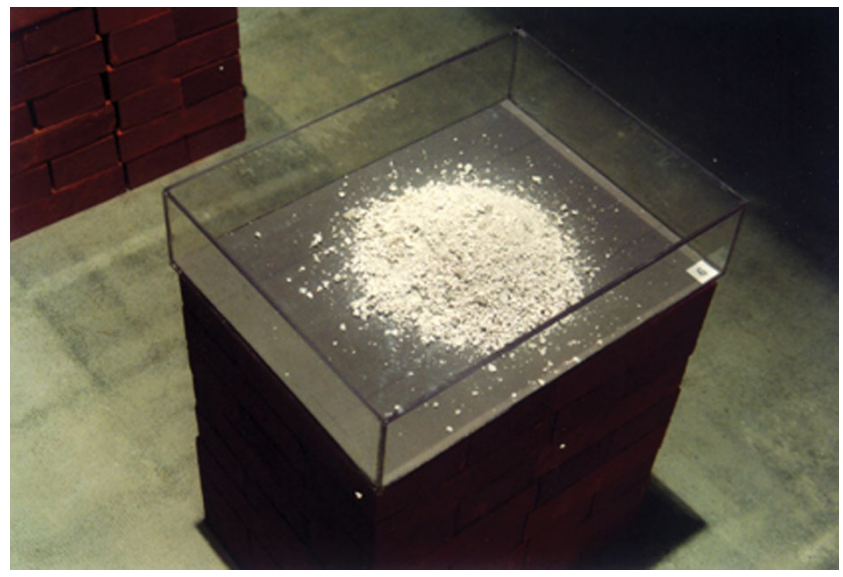

Unsaleable Goods (detail), 1993, Plexiglas, bricks, various powders, fur and hair, dimensions variable. Image courtesy the artist and Boers-Li Gallery.

《非卖品》(局部)，1993年，有机玻璃、砖、各种粉末、毛皮和头发，尺寸可变。艺术家及博而励画廊惠允。 


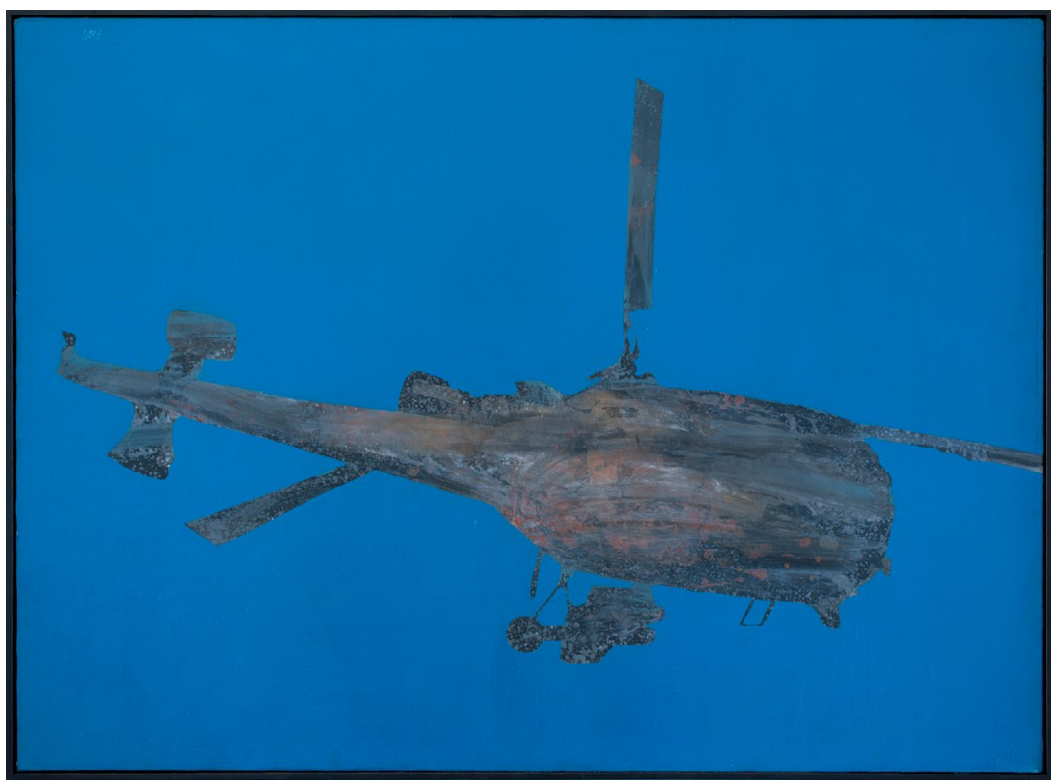

Flying Machine, 1994, oil on canvas, $110 \times 148 \mathrm{~cm}$. Image courtesy the Australian Centre on China in the World, The Australian National University.

《飞行器》, 1994年, 布面油画, $110 \times 148 \mathrm{~cm}$ 。澳大利亚国立大学中华全球研究中心惠允。
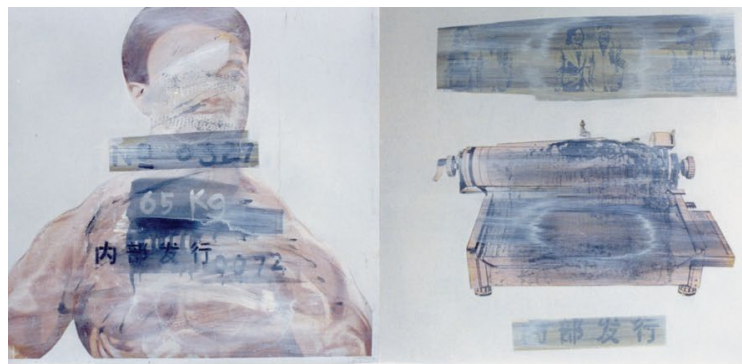

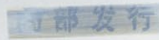

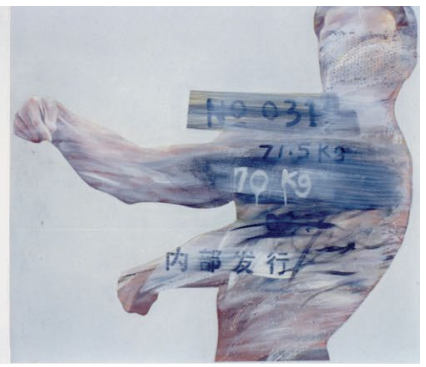

Chinese Bodybuilding: Syntax of 1989, 1991, oil on canvas, triptych, each $100 \times 80 \mathrm{~cm}$. Image courtesy the artist and Boers-Li Gallery.

《中国健美一一1989的措辞》，1991年，布面油画，三联画，每幅100 × $80 \mathrm{~cm}$ 。艺术家及博而励画廊惠允。 
1 Zhang Peili, from an Asian Cultural Council application statement, 1995. From Francesca Dal Lago, 'The Art of Not Looking Different', in Zhang Peili: Certain Pleasures, ed. Robin Peckham and Venus Lau (Hong Kong: Blue Kingfisher, 2011), 9.

2 On the genesis of the ' 85 New Space exhibition, see Katherine Grube's essay in this volume (p. 40). On the loose relationship between these groups, exhibitions and ideas, see Paul Gladston, 'Avant-Garde' Art Groups in China, 1979-1989 (Bristol: Intellect, 2013), 126-39.

3 On Zhang's Jazz series, see Dal Lago, 'The Art of Not Looking Different', 9.

4 It seems that Zhang may have reworked some shadows to heighten this effect. See, for example, what appear to be different iterations of Please Enjoy Some Jazz (1985), if one compares the image in Meishu [Fine arts], no. 2, (1986): 44; and that reproduced in Huang Zhuan and Wang Jing, eds., Zhang Peili: Yishu gongzuo shouce [Artistic Working Manual of Zhang Peili] (Guangzhou: Lingnan Meishu Chubanshe, 2008), 31.

5 Interview with Liu Libin in October 2005, in Huang and Wang, 451.

6 See Jane DeBevoise, 'The Debate over Luo Zhongli's "Father"', in Between State and Market: Chinese Contemporary Art in the Post-Mao Era (Leiden: Brill, 2014), 47-69. Compare Luo's earlier work People of Daba Mountain (1979), on p. 49, which includes a full-length portrait of a 'peasant' with a very similar face and headdress to Father, yet with a load of truck tyres on his back. The young man crouched beside him is dressed in more modern clothes and has a pack of industrial goods - all of which locates these peasants in a modernising China, at the advent of economic reform, rather than as archetypal nongmin.

7 See, for example, Zhang's early statement, on behalf of the Pond Society, against technical virtuosity: Shi Jiu [Zhang Peili], 'On New Space and the Pond Society (1987)', trans. Kela Shang, in Contemporary Chinese Art: Primary Documents, ed. Wu Hung and Peggy Wang (New York: Museum of Modern Art, 2010), 83-89.

8 See Huang and Wang, Artistic Working Manual, 44. For an example, compare the works (both titled X?) on p. $45,47$.

9 Zhang Peili, 'Language Itself Is a Form of Political Position', in Geti jingyan: 1989-2000 nian Zhongguo dangdai yishu shixiande duihua yu xushu [Individual Experience: Conversations and Narratives of Contemporary Art Practice in China from 1989 to 2000], ed. Liu Ding, Carol Yinghua Lu and Su Wei (Guangzhou: Lingnan Meishu Chubanshe, 2013), 182.

10 Zhang, 182.

11 E. J. Czerwinski, 'Towards a Poor Theater by Jerzy Grotowski (review)', Modern Drama 13, no. 1 (Spring 1970): 106.

12 See John Clark, 'Official Reactions to Modern Art in China since the Beijing Massacre', Pacific Affairs 65, no. 3 (Autumn 1992): 334-52.

13 My interview with Zhang Peili, 31 July 2017, Hangzhou.

14 See the December 2011 interview with Zhang titled 'Zijue de gongzuo' [Working towards self-awareness]', in Individual Experience, ed. Liu Ding, Carol Yinghua Lu, and Su Wei, 78. Also confirmed in my interview with Zhang, 31 July 2017.

15 Zhang, 'Working towards self-awareness', 79.

16 Zhang and Geng were brought in for questioning by police in September but were released later the same day. Zhang, interview with the author, 31 July 2017. For snapshots of the installed banners, see Jochen Noth, Wolfger Pöhlmann and Kai Reschke, eds., China Avant-Garde: Counter-Currents in Art and Culture (Hong Kong: Oxford University Press, 1994), 36. See also Hans Van Dijk, 'Painting in China after the Cultural Revolution: Style Developments and Theoretical Debates-Part 2: 1985-1991', China Information 6, no. 4 (Spring 1992): 15. He dated the action to 7 June.

17 'Working towards self-awareness', 78. It is interesting to consider Zhang's work alongside Hamilton's iconic collage Just What Is It That Makes Today's Homes So Different, So Appealing? (1956).

18 This is not merely metaphorical. According to Wang, Zhang Peili gave him a book of baotou ziliao (lit. 'newspaper masthead materials'; standardised illustrations of subjects including Mao Zedong, workers, soldiers, farmers, militias, agricultural work, etc., which artists and amateurs used as source books during the Cultural Revolution) which was the origin of Wang's Great Criticism series. See 'Wang Guangyi: Wohuoer de danchun bi fuza geng weida [Wang Guangyi: Warhol's simplicity is greater than complexity]', Xin jing bao [Beijing News], 9 October 2013, http://www.bjnews.com.cn/feature/2013/10/09/286413.html. 
19 Li Xianting, for example, lauded Chinese Bodybuilding: Elegance of 1989 (1989) and 1989 Standard Pronunciation (1989) for finding the 'national face' of China. See Li Xianting, 'Apathy and Deconstruction in Post-'89 Art: Analyzing the Trends of "Cynical Realism" and "Political Pop" (1992)', in Wu Hung and Penny Wang, Contemporary Chinese Art, 165.

20 My interview with Zhang, 31 July 2017, Hangzhou.

21 Jing Wang, High Culture Fever: Politics, Aesthetics, and Ideology in Deng's China (Berkeley: University of California Press, 1996).

22 A bikini-clad bodybuilder also features in an earlier artwork by another Zhejiang graduate, Zhao Jianren: Huozhe ju shang [Late starters get on top] (1988). See Van Dijk, 'Painting in China', 10.

23 Susan E. Brownell, 'Sports', in Handbook of Chinese Popular Culture, ed. Wu Dingbo and Patrick D. Murphy (Westport, CT: Greenwood Press, 1994), 127-28.

24 See 'China's Fear of the Bikini', Time, 15 December 1986, 48. I have also referred to a clip of the Shenzhen Television Station broadcast from 1986: www.youtube.com/watch?v=Atx33YcgX24. On the emergence of commercial opportunities for artists domestically, see DeBevoise, Between State and Market.

25 Zhang Peili, quoted in Huang Zhan, 'Lun Zhang Peili: yi ge guangnianzhuyi de fanti: [An Antithesis to the Conceptual: On Zhang Peili]', in Peckham and Lau, Certain Pleasures, 25-26. I have used my own translation, but another translation of Huang's article was published as 'An Antithesis to Conceptualism: On Zhang Peili', Yishu 10, no. 6 (November-December 2011): 8-22.

26 Susan Buck-Morss, The Dialectics of Seeing: Walter Benjamin and the Arcades Project (Cambridge, MA: MIT Press, 1991), 67. Zhang's earlier interest in the saxophone and jazz for his early series also seemed to relate, in part, to the improvised, layered nature of jazz music.

27 Buck-Morss, 222.

28 Wu Hung, 'Once More, Painting from Photos', preface to Chen Danqing: Painting after Tiananmen, by Ackbar Abbas (Hong Kong: University of Hong Kong, 1995), 10-13.

29 All quoted in Wu Hung, 'Once More, Painting from Photos', 11. Anecdotally, the now Australian-based painter of the well-known socialist realist work Standing Guard for the Motherland (1976), Shen Jiawei, showed me his sketchbook for this painting during a studio visit in 2011 ; I recall it included a number of posed black-and-white photos he took of men dressed like military guards, as studies for his final painting.

30 Pang Laikwan, The Art of Cloning: Creative Production During China's Cultural Revolution (London: Verso, 2017), 146. There is also Ai Weiwei and Britta Erickson, eds., The Richness of Life: The Personal Photographs of Contemporary Chinese Artist Liu Xiaodong (Beijing: Timezone 8, 2007). I thank Katherine Grube for both references. See also Wu Hung, 'The "Old Photo Craze" and Contemporary Chinese Art', in Zooming In: Histories of Photography in China (London: Reaktion, 2016).

31 Zhang has confirmed that the bodybuilder image for China Bodybuilding: Elegance of 1989 (1989) was from a 'sports magazine'; it may have been Jian yu mei [Health and beauty], launched in 1980, at that time one of the leading magazines to feature bodybuilding. My interview with Zhang, 31 July 2017, Hangzhou.

32 My interview with Zhang, 31 July 2017, Hangzhou.

$33 \mathrm{Wu}$ Hung has written on the place of television in Chinese contemporary art, in which Zhang's work is discussed in detail. Wu perceptively argues that while Chinese artists have reflected on television they have not really intervened in its system, which remains the purview of the state. Zhang's work Water: Standard Version from the Cihai Dictionary (1991) arguably comes closest to a détournement of part of this state system. Wu Hung, 'Television in Contemporary Chinese Art', October 125 (Summer 2008): 65-90.

34 Zhang Peili: Chine, exhibition at Galerie du Rond-Point, Paris, 8 January-7 March 1993.

35 My interview with Zhang, 31 July 2017, Hangzhou. Note, Assignment No. 1 is commonly dated 1992, but Zhang says he went to Beijing in 1990 to undertake the post-production on the footage. It was through a connection in the post-production company that he was able to arrange for Xing Zhibin to be filmed for the video Water: Standard Version from the Cihai Dictionary (1991).

36 Incidentally, $30 \times 30(1988)$ was also shown on three monitors, though from a single video. For a detailed list of each work, including its dimensions and components, see 'Zhang Peili', in Zhongguo xiandai yishu de neibu jiaoliu ziliao / Hei pi shu [China modern art materials for internal circulation / Black cover book], ed. Zeng Xiaojun, Ai Weiwei and Xu Bing (1994), 72-75. Also, my interview with Zhang, 31 July 2017, Hangzhou. 
37 Of these materials, Zhang brought the coal slack (the residue from making bricks of coal), calcimine (used for whitewashing walls) and lime from China. See Huang and Wang, Artistic Working Manual, 17273, which includes an installation view. I discussed this work in my interview with Zhang, 31 July 2017, Hangzhou.

38 Zhang Peili, exhibition at Galerie Crousel-Robelen [now Galerie Chantal Crousel], Paris, 29 May-17 July 1993. See Huang and Wang, 174-75. Zhang completed a related installation in Spoleto, Italy, also in 1993 , without plaster but instead with sheets of wax cast directly on the floor. Neither wax works were completed according to Zhang's plans, compromised by lack of time and materials. My interview with Zhang, 31 July 2017, Hangzhou.

39 Pauline Yao, 'The Distance Formula: Viewer Interaction in the Art of Zhang Peili', in Peckham and Lau, Certain Pleasures, 35.

40 Zhang took 'many years' to complete Flying Machine and its companion pieces, and it may have been precipitated by the necessity to move the work from the studio he was using in the school where he taught. Zhang said he originally set out to paint the helicopter in detail, and only eventually came to this layered resolution. He also suggested that the colours may have changed along the way, so the painting pictured in the Artistic Working Manual (p. 185) may have been an earlier iteration, though I cannot make out any significant differences, besides the intensity of colour. My interview with Zhang, 31 July 2017, Hangzhou.

41 Zhang had painted a mimeograph machine in profile in 1987, as a symbol of media, since before the 1990s, unofficial 'publications' were printed with this machine-including the Pond Society group statement, as well as Zhang's text work Art Plan No. 2 (1987). See Huang and Wang, Artistic Working Manual, 78-79. Incidentally, above the mimeograph is a print of a smiling wedding couple from the Cultural Revolution era; Zhang took this image to his residency at Art Omi, in the United States, the following year, where it featured in his painting Red Wedding (1992).

42 Though I have not asked Zhang, this may also be a source of military imagery at that time, and in turn a way to indirectly refer to the military action in Beijing in 1989. From 1990, Xu Tan, who had been painting the Guangzhou meat markets, began to paint tanks, allegedly referring to the Gulf War, in works such as The Nineties: Untitled No. 2 (1990-91). See Noth, Pölhmann and Reschke, China Avant-Garde, 279.

43 Personal correspondence with Lois Conner, 31 January 2019.

44 See Jane DeBevoise and Anthony Yung, 'The 1992 Guangzhou Biennial Art Fair', Post: Notes on Modern \& Contemporary Art around the Globe, 21 April 2015, www.post.at.moma.org/content_items/590-the1992-guangzhou-biennial-art-fair. For a broader discussion of the art market in China at the time, see DeBevoise, 'Big Business, 1990-93', chap. 4 in Between State and Market.

45 Zhang has succinctly identified 1993 as a turning point for Chinese contemporary art, for these reasons; see 'Conversation between Zhang Peili and Zhu Jia', in the exhibition brochure for Not Only Time: Zhang Peili and Zhu Jia, REDCAT, Los Angeles, 17 September-21 November 2010, www.redcat.org/sites/redcat. org/files/gallery/linked-files/2011-06/NOT_BROCH_15A.pdf. For an art-historical overview of these issues, see Peggy Wang, 'New Audiences, New Energy: Producing and Exhibiting Contemporary Chinese Art in 1993', Post: Notes on Modern \& Contemporary Art around the Globe, 19 August 2015, www.post. at.moma.org/content_items/612-new-audiences-new-energy-producing-and-exhibiting-contemporarychinese-art-in-1993.

46 Dal Lago, 'The Art of Not Looking Different', 9.

47 The English text appeared under the title 'In War with the West? [sic]', in China: Aktuelles aus 15 ateliers [China: Recent works from 15 studios] (Munich: Hahn Produktion, 1996), 133-35. Zhang apparently wrote this when requested for a catalogue text by Hans van Dijk, curator of that exhibition.

48 The year 1996 was also when Shanghai artist Qian Weikang was leaving the art scene, apparently in part out of frustration at its opportunism. He was critical of artists 'too busy looking to London, New York and the Biennales.... Yet they have never paid attention to the world in front of their noses. When artists call themselves 'avant-garde' I jokingly tell them: in China there are two kinds of people who call themselves avant-garde, one is the Communist Party, who refer to themselves in the Party constitution as the vanguard of the people; the other kind are artists.' See Biljana Ciric's interview with Qian in Shanghai $\tan$ 1979-2009: Shanghai yishujia gean [History in the Making: Shanghai 1979-2009: Artists Interviews and Work Archives] (Shanghai: Shanghai People's Fine Arts Publishing House, 2010), 274.

49 See the discussion by Orianna Cacchione in 'Related Rhythms: Situating Zhang Peili and Contemporary Chinese Video Art in the Globalizing Art World', Journal of Contemporary Chinese Art 5, no. 1 (2018): 32-33. 


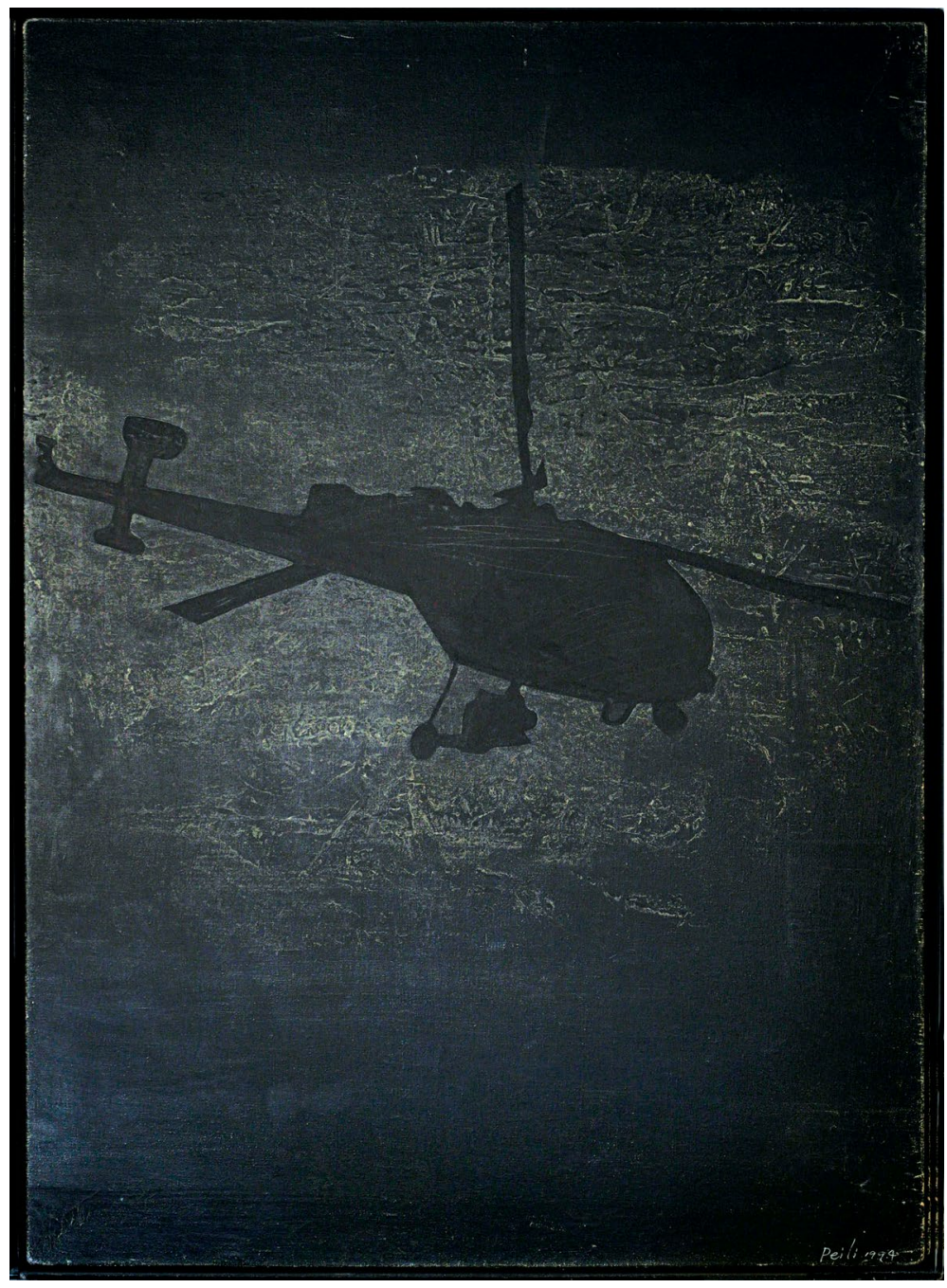

Zhang Peili, Flying Machine, 1994, oil on canvas, $148.5 \times 107 \mathrm{~cm}$. Image courtesy Lois Conner.

《飞行器》, 1994年, 布面油画, $148.5 \times 107 \mathrm{~cm}$ 。康兰丝惠允。 


\title{
张培力的《飞行器》与
}

\section{中国当代艺术中绘画的目的和消亡}

\author{
柯惟 \\ Olivier Krischer
}

张培力的创作通常被认为是由绘画往录像平稳转向。1988年, 张培力完成了中国第 一件录像作品, 并于 1991 年展出了第一件中国录像艺术。之后, 他一直致力于创作 更复杂的录像装置。然而, 作为张培力最后几张绘画作品之一, 《飞行器》（1994 年）的重新出现, 让我们不禁察觉, 即使像张培力这样的艺术家, 亦需持续直面其所 受的学院训练。油画, 对于张来说, 不只是一种技术而是一种“语言”。

1995年, 在纽约长达10个月的驻留期间, 张培力写道: “艺术的作用是消除障 碍, 这也是它的意义之所在。因此, 我的出发点是日常生活和平凡经验。我希望我 的作品能够站在艺术和生活之间，或者，换句话说，在一个无限的边界之上。”

《飞行器》标志着张培力在寻求表达绘画的中间态与不定性中到达的顶峰, 他在制 作其它开创性的录像和装置的过程中完成此作。

在此, 我认为值得思考的是, 张培力是如何通过不同的媒介探讨共识性的话题和主 题。例如, 符号及其所指之间的持久张力; 对观念的重复、复制、繁衍, 尤其是接 受。这些问题植根于张培力的早期创作实践中。虽然, 从20世纪90年代中期开始, 张培力便专注于探讨录像装置的可能性, 但本文试图找回绘画在其千锤百炼的艺 术“语言”中的作用。由此，让人思考艺术家跳脱于固有叙事的不同之处。

\section{艺术与生活}

首先, 我们有必要思考张培力绘画实践的长期发展。1984年毕业后的一系列小组活 动、展览与个人作品, 以及1987年开始背离绘画, 让 “语言” 的观念成为张培力艺 术实践中的一个核心问题。1984年第六届全国美展中所体现的倒退的保守主义, 让 包括张培力在内的很多人都感到沮丧。“浙江青年创作社”松散地集结了这些艺术 
家。没有任何宣言, 也没有共同的美学使命, 他们最初聚集在一起是为了筹措资金, 去组织一个截然不同的展览。这便是 “85新空间画展” , 其开创性意义已被广泛认 同。张培力与其他参与者立刻意识到将艺术更直接地带入公共空间的必要性, 让艺 术 “渗透” 到日常生活之中, 由此催生了次年在杭州成立的池社。这个小团体创作了 瞬时性的公共艺术装置与行为表演。2 同样是在 1986年, 张培力开始了《X? 》手套 系列的创作, 并试图将绘画从叙事的 “负担” 中解放出来。张的个人创作与池社的作 品, 对85新潮旗帜下日渐正规化的新兴艺术做出了批判性回应。

张培力早期绘画的主题似乎常常是对具体的个人经验的升华与概括, 无论是爵士乐系 列中其兄的萨克斯管, ${ }^{3}$ 还是 《X? 》中的唤起记忆的医用手套一一父母的工作与自身 年幼的患病经历, 让他成长于医疗环境之中。“85新空间画展” 中的画作呈现出一种 隐秘的现实主义; 由此, 眼见而并非真知。虽然被标签为 “冷漠”, 这些画并非是单 调或无趣; 它们将都市群体之间的隐匿、纠结与不可思议的孤绝囊于其中。突元的阴 影使身体和面部变得光滑, 使人物乏于个性, 甚为一般。有时, 他们面容缺失, 回避 或无法对观众的凝视作出回应（见第64页）。4

此画基于张培力、耿建翌及其同辈发展出来的批判性取向, 主要反驳社会主义现实主 义。不单是就其风格而言, 而是作为一套 “语言” , 批判其 “叙事主义” 和历史使 命 “削弱了绘画的内在价值”。 ${ }^{5}$ 他们对社会主义现实主义的批判从其根源, 即十九 世纪晚期俄罗斯的 “流浪学派” (Передви́жники, Peredvizhniki) 开始, 延伸到新 近的趋势 “伤痕艺术”和 “乡土现实主义”。从“语言”上说, 张培力和他的同仁认 为它们并没有根本上的不同。例如, 罗中立的《父亲》（1980年）将 “真正的”农 民带入保守的中国学院派油画中, 这看似激进, 但并未改变艺术与社会的关系。这类 绘画以其特有的政治和技巧价值，提供了一种新的模式，并很快被体制吸纳。6

这种新的油画趋势也让人致力于提升精湛的技巧, 因此进一步将艺术家作为技术的精 英一一和艺术作为一种技术一一与日常生活疏离。张培力和他的同仁们对技巧以及 作者的主观性都保有警惕, 因为, 两者都是学院式训练的标志。 7 对于《X? 》系列, 按张培力的最初计划, 他要为相同的手套绘制100个版本, “使用重复来消除每件作 品之间的差异。” 8 在完成了的二十多幅手套画中, 他刻意使用柔和的色调, 并以一 种学究的方式绘制, 好像任何受过训练的人都可以达到相同的结果。重要的是, 这 些绘画并不完全相同, 但它们之间的差异并不足以使它们成为不相关联的观赏或分 析对象。它们达到了千篇一律的效果, 在视觉和观念上相互模糊, 共同成为了“手 套画”。然而, 它们仍保有现实性, 而非倾向于形式上的抽象。因此, 在手套画中, 任何叙事（例如记忆）几乎完全与观者在一起（见第70页）。9

对于张培力而言, 在 《X? 》系列中对绘画的构思和执行的程序性和脚本化的行为, 已经标志着他对绘画实践的叛离。此种探索也能在池社中找到根基。纯文本作品包括 手写的14页计划《先斩后奏——关于 “X? ” 的创作和展览程序》 (1987年), 和油 印文本《艺术计划第二号》 (1987年), 进一步完全消除了“视觉性”。这种介于艺 
术家、观众、媒介以及作品发生的创造性空间之间的概念化关系受到了卡夫卡的影 响, 同时, 特别是波兰剧作家耶日 - 格洛托夫斯基（Jerzy Grotowski）的《迈向质 朴剧场》（1968年）的影响。10 正如一篇当代评论所观察到的那样: “对格洛托夫斯 基来说, 剧院不单是一个戏剧演出的地方, 也不仅是我们可以安全观看文化另一个方 面的地方： [它]是一个必须打开的潘多拉盒子, 因为探索的仪式是对人类唯一有意义 的事情。” 11

在上世纪80年代的理想主义中，大多艺术仍是超然性的。许多人渴望 “纯粹”，但在 理论方法和实践方面又存在着明显的差异。例如, 王广义领导的北方艺术群体作品中 的准神秘场景, 被看作与张培力和其他杭州同仁的某些绘画方式一致, 即“理性绘 画”。北方艺术群体当时渴望与世界性的传统达到一种“崇高”的融合, 这体现在中 国东北的后工业风景中，色调深灰，表达庄严。1987年至1988年间，池社观念性探 索和张培力与之密切相关的个人实践, 是对把新兴艺术历史化和包装成一种“运动” 所作出的批判性回应。

\section{9年之后的绘画}

如果说，1989年2月，“中国现代艺术展”对挥之不去的集体性目的提出了明确的挑 战性的结论, 那么, 中共对 6 月抗议运动的暴力镇压, 特别是随后全国范围内对文化 行业的施压，使得20世纪80年代出现的艺术一一用张培力的话说一一显得如此虚弱 和深涩, 甚至幼稚。13

被1989惊醒之后, 张培力觉得艺术就像是 “你无法去挠的痒”。他希望自己的作品 更加“具体”，但不一定是像经典的美国波普艺术那样“中立”或 “积极”地对待 现实。张培力试图创造一种 “提示”，而不是传达判断。14 “当时，我觉得我以前的 概念图作品、方案和录像都有点形而上, 与现实有点太遥远。从那以后, 有一段时 间，我想通过我原来的绘画实践来回归现实。” 15

事实上, 1989年6月7日, 根据国际新闻媒体发布的北京受难者照片, 张培力和耿建 翌制作了两幅大画, 每幅7米长, 3米宽。他们举着画在杭州市中心游行, 然后将画 悬挂在天桥上。而张培力却说, 他们并不认为这是一件艺术作品。1 ${ }^{16}$ 那一年, 张培 力的第一件作品是一幅混合媒体绘画, 名为《中国健美一一1989的风韵》(1989年) (见第70页), 看上去与他的《X? 》系列截然不同。张培力将此描述为 “扁平绘画, 就像广告”，作品具有拼贴效果，其中包括邮票、旧的粮票（象征着社会主义经济 的飞速消退), 以及进口女性化妆品的标签, 给人一种刻意直白的时髦感。画面中央, 占主导地位的是一位中国女子健美冠军, 牙齿洁白闪亮, 时髦地恣了短发, 举着一 个奖杯一一右下方像 “盖章” 似的显示了她的参赛体重。在她的上方和下方, 重复 排列着一个个文革剧团演员的头像。更显眼的是, 画面左侧列着七个字的官方口号:

“翻身不忘共产党”。任何一个成年人都能够在心底默默说完这个曾经无处不在的口 号的下半句: “幸福不忘毛泽东”。张培力承认这件作品与政治波普的表面关系— 
评论家兼策展人栗宪庭很快便对此类型展开了描述一一但张培力却与 20 世纪 50 年代 理查德 - 汉密尔顿（Richard Hamilton）更具自反性的波普艺术联系起来, 这源于 拼贴, 而非绘画。17 如果我们将《中国健美》与王广义的《大批评》系列（经常被视 为政治波普的经典范例）进行比较, 王广义的绘画将文革 “样板” 图像与西方商业品 牌相结合，用自己精心设计的大众消费文化海报取代文革时期的政治霸权。1 ${ }^{18}$ 张培力 的作品虽同样是色彩明亮、䎦俗, 及“文本性” 强, 但却更显慎重。他的“波普”是 国民性的; 虽因为政治和流行的原因而易于辨识, 但这种比较并未描绘出关于“社会 主义”或“全球化”，甚至是“中国”的整体图景。19

《中国健美一一1989的风韵》（1989年）将流行文化和社会历史中的不同元素并 置, 虽相比于他早期的作品带有更直接的象征性, 但仍很难将其局限于特定的、共识 的意义。即使 《X? 》系列中的手套是一个暗示性的 “中间对象” , 张培力这一系列 中的健美运动员体现了一种不确定的状态。张培力感兴趣的是对健康的追求与过度追 求之间的紧张关系, 这些训练有素的躯体显得美丽又俗气。20 在20世纪 80 年代的中 国语境下, 健美与 “生活方式” 的进步以及电视新媒体景观相交叉。作为自下而上的 流行文化，健美运动不同于政府的保守主义以及知识分子盛行的“高雅文化热”。21

健美运动在共产主义中国是被禁止的, 源于政府对于 “裸体” 的否定态度和规定, 尤 其是针对女性而言, 再而, 还可能是因为它未被纳入奥林匹克体育项目。这是关于自 我形象和个人抱负, 而不在于国家的荣耀。22 尽管该禁令于 1983 年被解除, 但参赛 的女性一定要穿着正统的一件式泳衣。直到1986年, 当局才允许女性穿着比基尼参 加在深圳这个新兴的经济特区举办的锦标赛。 ${ }^{23}$ 虽然参赛者都只是业余爱好者, 但 通过电视转播一配上流行音乐和聚光灯效的烘托, 以及评论员对每个参赛者的职业 和出身的介绍一一这显然是商业机会和管制放松的本土结合, 反映了媒体新的商业需 求，改变中的公众趣味，以及由市场取代或扩大国家资助的潜力。24

众所周知, 张培力的作品是在避免文化符号主义。但对张培力而言, 在生活中的偶然 性 “元素” 与带有功利性和战略性的身份 “符号”之间, 存在着重要的区别。“符号 可以被功利性地使用, 但也能以解构性或断裂性的方式使用, 人们可以称之为创造性 的方式。这两种方法完全不同; 只有其中之一会传达新的理解。但是, 当符号被简单 地用作表达身份的策略时, 这是有问题的……我反对单一的文化心理学、固定的观察 或理解模式。”25

《中国健美》中的视觉组合并不是由新的组件构成, 但代表了新的关系。这些元 素的排列和分层并列, 传达出一些新的见解, 并回应了瓦尔特. 本雅明 (Walter Benjamin）计划用来构建他未完成的作品《拱廊计划》中的拼贴和蒙太奇概念。他 曾写道, 蒙太奇 “打断了它所被嵌入的语境”, 从而 “反制于幻觉”。26 为了捍卫自 己的态度, 他坚持道: “我无话可说。只有去呈现。” 27 
张培力使用的元素来源于媒体出版物, 并提出了绘画与摄影的关系, 或者, 更确切地 说, 是复制图像, 这是一个在中国当代艺术话语中少有讨论的话题。在为写实画家 陈丹青撰写 的一篇画册文章中, 巫鸿从文化大革命开始, 追溯临摹照片作为中国油 画“主要特征”的绘画实践。28 使用照片不是因为缺乏现实的主题, 而是与“真实性 和理想化” 的困境有关。大量 “典型” 图像通过报纸、杂志和电影进行复制和流通, 这个过程给照片图像带来了具有历史感的档案品质。因此, 基于照片图像的绘画可以 分享这种已达成共识的“真相”，潜在地使艺术家免于被指责具有错误的个人主义倾 向。由此, 艺术家开始收集杂志和新闻剪报, 甚至争相采用标志性图像。29 彭丽君 (Pang Laikwan) 认为, 这种模式和复制文化是 “社会性模仿” 计划的一部分, 源 于20世纪40年代早期, 但在文化大革命期间达到了顶峰。30

1989年至1994年, 张培力绘画中的所有人物形象都不是标准的“模范” 人物, 而是 通过保留裁剪的边缘, 战略性地突出其来源于印刷媒体, 如《中国健美》中被裁剪的 健美运动员的腿, 或者, 在《幸福生活来自TV》（1991年）（见第77页）双联画中 重复的新闻播报员。 ${ }^{31}$ 这也是张培力 1992年在纽约Art Omi驻留期间（他的第一次 海外之旅）创作的《婚礼》和《士兵》系列的一大特色。 ${ }^{32}$ 其三联画《水-1989 的标准发音》（1990年）, 作为其1991年的视频《水——辞海标准版》（1991 年）的先行之作, 描绘了电视屏幕上因被拍照而产生的闪炼着的雪花噪点的连续帧 画面。33

虽然, 《X? 》系列也是绘制自照片, 但在没有物体或表面轮廓的祄托下, 手套看 上去是弯曲并悬置的。但是, 1989年之后, 张培力的绘画突出了图像的图像之地 位。受惠于电视屏幕而不是剧场, 这些作品没有任何空间深度的修饰。在这里, 媒介 (而不是 “媒体”) 本身的权力或权威成了一个关键问题, 张培力试图利用绘画的造型 质性一一它操纵尺寸、形状、密度、颜色和印刷——以重铸这些元素在它们的来源和 观众之间的重要距离。

通过这些绘画, 张培力回归的“现实” 并不是平滑的, 也不是整体的, 它同时成倍 增长和分裂于不确定的图像、半透明的层次、丝网印刷的重复、以及蒙太奇的排列 中。这些作品的界限明确并不可否认, 无论是形式上还是概念上, 都是作品 “语言" 不可或缺的一部分。

在双联画《幸福生活来自TV》（1991年)中，新闻播报员罗京（和邢质斌一样,都 是每晚《新闻联播》的著名主播）被画在两幅画布上, 像是两幅重复的丝网印刷作 品, 但每幅画都有微妙的不同。罗京和所有其他元素都在画布边缘之内, 这强调了 它们作为图形二维性。这种二维性以不同密度的单色裁剪的图像, 分层覆盖其上而 得以强化。每块画布的组合是相同的。这种相同效果、表面重复但实则相异的方法 也重复应用在每块画布上两个较低的图像上, 即以画面底部两组有细微差异的数 字：44-722和44-723来加强此种效果。 
1993年初, 张培力在巴黎世界文化宫圆点画廊举办了首个重要个展。展览中的每件 作品都以不同的方式呈现出媒介的复制（或重复）和转换, 以及介于重复与区别之间 的紧张关系。34 例如, 在摄影装置《连续翻拍25次》（1993年）中, 张培力拍摄了 一个微笑的“农民”形象（选自1970年的《人民画报》），带到巴黎后，再让一位 摄影师制作了25份连续的拷贝, 由此, 黑白图像变得越来越颗粒状、斑驳和抽象。这 件作品一字排开展示, 说明了从清晰的原件到最终的“复印件” 的过程。

在同一个展览中, 张培力首次展出了《作业一号》（1992年）。作品是由六个频 道、十二个电视显示器组成的录像装置, 播放着手指被刺穿的采血过程的特写。录 像在后期制作中剪辑并转变成不同颜色的频道。35 即使录像作品《（卫）字3号》 (1991 年) 也不是作为多频展示的, 而是从原始磁带连续导出五个副本, 每个稍微降 级重复, 在五个独立的显示器上播放。36

在这次展览中, 张培力还创作了一件新的装置作品, 它同样探测了材料和身份之间 的 “不确定边界”。混合媒介作品《非卖品》(1993年, 见第77页), 由一排陈列柜 组成, 里面展出了形状相似的粉末堆。虽然, 原始材料是多种多样的, 但它们在被磨 成细粉之后变得相同, 换句话说, 按张培力的记忆, 它们被磨成尽可能地小, 但能 同时具有形态。这些材料都是基本的日常用品, 并且在很大程度上是全世界通用的, 包括：面粉、盐、奶粉、动物的毛和皮、人发、骨头、石膏、铁粉、煤渣、钙和石 灰。 ${ }^{37}$ 在同一年晚些时候, 张培力在巴黎举办了另一个个展, 并完成了一个相关的 装置。这次他使用石亳翻制了画廊地下室的一个方形地面。然后他用蜡为石膏模翻制 出蜡模, 再把石膏模 (负片) 和蜡模（“印出品”/正片）堆叠在被 “复制” 了的方 形地面上。38

\section{飞行器}

这些多样化的作品启动了一个在张培力后来的媒体装置中被描述为“激活” 观众的过 程。这个过程 “引发的真实互动不仅是在观众和艺术品之间, 而是在观众与自身之 间。” 39 至少是从 《X? 》系列开始, 张培力的作品提供并揭示了观众在观看过程中 的偶发位置。《飞行器》具有类似的功能。在这幅画中, 通过使用比例和透视、纹理 和简化的配色方案, 张培力不希求挪用图像的象征力量, 而是力图中和或释放它, 以 开放图像其它的可阐释性。

在《飞行器》中, 一个阴沉的形状悬挂在一大片光滑的蓝色上（见第78页）。我们识 别出直升机的头与尾, 以及旋转的螺旋桨。但从更近的距离看, 发现这是相机拍摄 的角度。物体在一段时间内变形及变平, 但它不再是快照。除了它的轮廓之外, 没 有任何叙事细节, 但这个不确定的边界一一实则是一个概念一一将它是什么与它不 是什么区分。我们无意去识别一种或能揭示此庞然大物的历史、功能、政治或忠诚 的模式。所有这些都是平坦的、平滑的、聚合的。剪影最后由精心涂上的厚厚的蓝 色油漆层组成, 结合蓝白色的半透明笔触, 遮罩着下面的炭黑, 滴状灰和宝红褐。40 
被遮罩的主体和动作式的涂层表明一种正式的关系并反映在作品中, 比如三联画 《中国健美一一1989的措辞》（1991年，见第78页）。画中描绘的两位男性健 美运动员, 一个油印机和“内部发行” 字样, 表明了材料仅限于特定领域的专业用 途, 不适合公共消费。41 也正是在这个时期, 1991 年至 1992年, 军事图像开始出 现在张培力的一些画作中, 例如, 为 1993年威尼斯双年展制作的大型五板画《玫瑰 红与灰》（1992年), 这也许受到了海湾战争（1990年至1991年）和波斯尼亚战 争（1992年至1995年）的启发。42 《张培力艺术工作手册》中两幅直升机作品, 被 看作是其最后的画作。但是, 康兰丝收藏了另外一幅没有记录的直升机作品, 让在 堪培拉的油画, 以及这个系列, 阐发了新的方向。43 康兰丝的这幅 “黑调”《飞行 器》(见第82页), 带着暗沉、烟熏般的色调, 底下隐约透着黄光。正如其 “蓝调”

《飞行器》, 张培力使用了直升机的剪影, 并用重复的模式来削减意指的客体。不 过, 如果堪培拉的《飞行器》中的纹理涂层被蓝色平滑地掩盖, 康兰丝藏有的《飞 行器》中暗黑的油漆则显得无所拘束。油彩之上有意为之的数条长刮痕, 提示着画作 的物理性质, 并玩赏于形式抽象与具体实物之间。总而言之, 张培力似乎在寻找表现 与抽象, 表现与形式之间的绘画习语。

\section{入世}

中国当局对 1989事件的剧烈反应的讽刺性后果之一, 便是其迅速转向经济发展。而 各行各业的大多数人也都热切跟从。早在 1990 年, 中国第一家证券交易所在上海成 立, 次年中国油画首次在香港拍卖。到了1992年, 邓小平在春节南巡期间发表了一 系列声明, 呼吁发展 “社会主义市场经济”, 并建立多个经济特区。许多主要的艺 术家和评论家都变得富有创业精神, 他们在市场上找到了国家准许或赞助的替代方 案。1992年, “广州首届九十年代艺术双年展”, 诚如其英文标题, 是以私人赞助 为组织方式。作为大型的商业展览, 其提供了 20 多个现金奖。在当时而言, 这极为 新鲜。但因对收入过渡乐观的预测而导致开销超过收入, 最终揭示了组织者的理想主 义和缺之经验。44

在同一时期, 像许多重要艺术家一样, 张培力很快就有机会到国外旅行和举办展 览。正是在这种背景下, 1994年, 张培力决定性地将绘画放在一边, 感觉这种媒 介已经与 “生活”过于疏远; 他无法摆脱他在艺术学校接受的训练。在 20 世纪80 年代, 张培力和其他人试图拓展绘画 “语言”, 但在很大程度上, 通过经济和文化 发展, 这已被纳入现代化和民族救赎的叙事当中。特别是从1993年开始, 随着中国 “走向世界”，人们感觉到中国艺术也正在全球重新获得重要地位。中国艺术的形象 也受到越来越有影响力的策展和艺术批评话语的影响, 例如绘画的主导地位, 特别是 政治波普和玩世现实主义风格的作品, 经过 1993年的威尼斯双年展和同年的“后89 中国新艺术”等展览后确立起来。45 
然而, 由此发展出的对此种影响的批评也倾向于批判其文化沙文主义。即使张培力在 其作品中明确地提出 “形式中立” 46 , 但其在 1996年为慕尼黑的一个群展撰写的文章 《与西方作战? 》中, 也提到了此种趋势, 即中国年轻评论家倾向于将艺术框入奥 林匹克式的竞技之中 47 , 将艺术成就甚至是美学问题, 与超越 “西方” 的民族野 心混为一谈。48 在20世纪90年代中期的语境中, 张培力对作为创作媒介的绘画的 多次舍离（1986年左右, 以及1994年之后）可以看作是一种持续的拒绝。拒绝 满足于无论是来自国家还是全球艺术市场的简单的（和有利可图的）身份政治,张 培力致力于耕修一个第三空间——— 《 《飞行器》悬停的空间——于 “不确定的边 界”之上。49

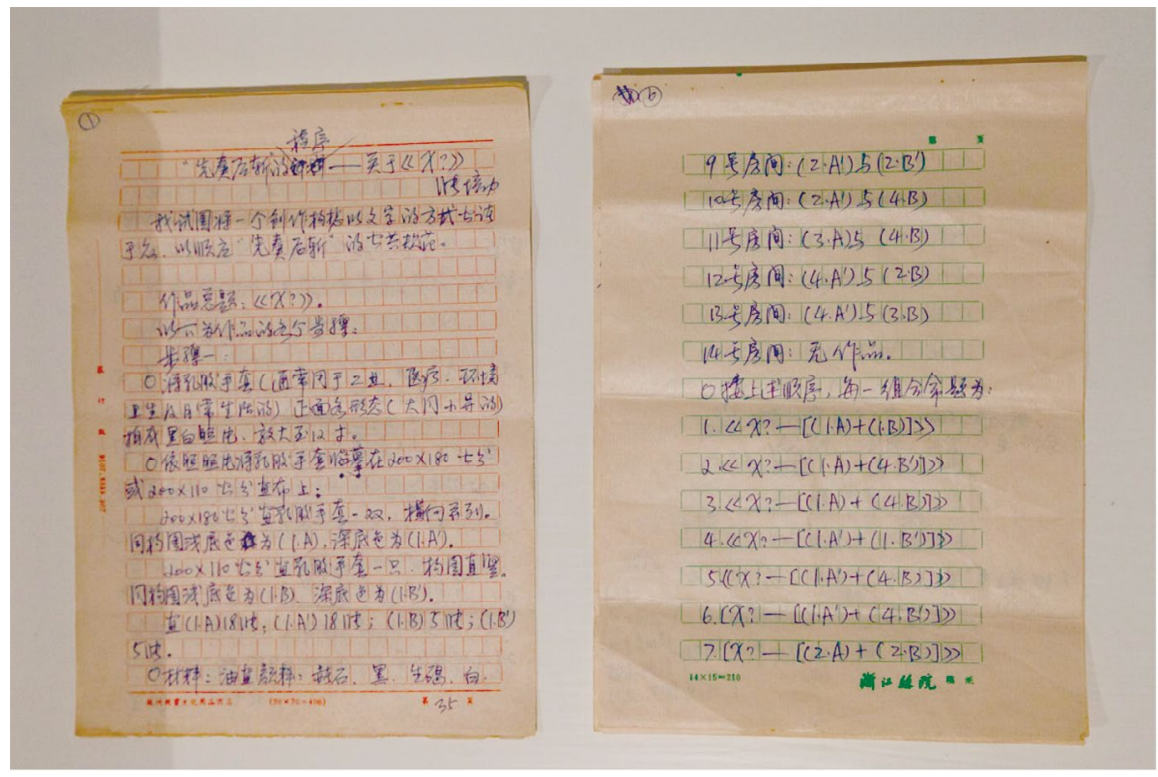

Procedure of "Ask First, Shoot later": About "X?", 1987, pen on paper, 14 handwritten A4 pages (Detail). Image courtesy the artist and Boers-Li Gallery.

“先奏后斩”的程序一关于 《“X?”》，圆珠笔，14张手写A4纸页（节选），1987年。艺术家及博而励画廊惠允。 
1. 张培力选自《1995年亚洲文化委员会申请声明》，㚕兰（Francesca Dal Lago）：《非不同寻常的艺术》，岳鸿飞、刘秀仪 编: 《张培力: 确切的快感》, 香港: Blue Kingfisher出版社, 2011 年, 第9页。

2. 关于 “85新空间” 展览的起源, 参见本书古婷婷 (Katherine Grube) 《85新空间画展：激进实验与学院》。关于这些群 体、展览和观念之间的松散关系，参见保罗·葛思谛（Paul Gladston）：《中国1979至89的“前卫”艺术团体》，布里斯 托: Intellect出版社, 2013年, 第126-39页。

3. 关于张培力的爵士乐系列, 参见茀兰: 《非不同寻常的艺术》, 岳鸿飞、刘秀仪编: 《张培力: 确切的快感》, 香港: Blue Kingfisher出版社, 2011 年, 第9页。

4. 张培力似乎在阴影上重复绘画来提升这种效果。例如, 《请你欣赏爵士乐》（1985年）在《美术》杂志中刊发的图像（1986 年, 第2期, 第44页）, 和黄专和王景编：《张培力：艺术工作手册》（广州：岭南出版社, 2008年, 第31页）中的图像, 出 现了看似不同的重复。

5. 2005年十月, 刘礼宾对张培力的访谈, 黄专和王景编: 《张培力艺术工作手册》, 广州: 岭南出版社, 2008年, 第451页。

6. 参见杜柏贞 (Jane Debevoise) 《关于罗中立 ‘父亲’ 的辩论》, 《国家与市场之间: 后毛泽东时代的中国当代艺术》, 莱 顿：博睿学术出版社，2014年，第47-69页。比较罗中立早期的作品《大巴山农人》（1979年），如第49页图片所示，其中 包括一张 “农民”的全身肖像, 脸上和头饰与父亲非常相似, 但背面有一堆卡车轮胎, 那个蹲在他身边的年轻人穿着更现代的衣 服, 还有一包工业用品, 所有这些都将这些农民置于现代化的中国，随着经济改革的到来，都已不是典型的“农民”。

7. 例如, 参见石久 (张培力) 代表池社反对精湛技术的早期陈述, 《关于“新空间”与“池社”》, Kela Shang译, 巫鸿、王 必慈（Peggy Wang）编：《中国当代艺术：基本文献》，纽约：纽约现代艺术博物馆, 2010年, 第83-89页。

8. 参见黄专和王景编: 《张培力艺术工作手册》, 第44页。例如, 比较45页和47页上的作品《X? 》。

9. 张培力: 《语言本身就是一种政治立场》, 刘鼎、卢迎华、苏伟编: 《个体经验: 1989-2000年中国当代艺术实践的对话与 叙述》, 广州: 岭南美术出版社, 2013年, 第182页。

10. 同上

11. E.J. Czerwinski: 《迈向质朴剧场书评》, 《现代戏剧》, 第13卷, 第1期, 1970年春, 第106页。

12. 参见姜苦乐（John Clark）：《北京大屠杀以来中国当局对现代艺术的反应》，《太平洋事务》，第65卷，第3期，1992 年9月, 第334-352页。

13. 基于笔者2017年7月31日, 在杭州对张培力的专访。

14. 参见2011年12月的张培力访谈, 标题为《有意识的工作》, 刘鼎、卢迎华、苏伟编: 《个体经验: 1989-2000年中国当 代艺术实践的对话与叙述》, 广州：岭南美术出版社, 2013年, 第78页。笔者在2017年7月31日的于杭州的采访中也证实了 此点。

15. 张培力: 《有意识的工作: 张培力》, 刘鼎、卢迎华、苏伟编: 《个体经验: 1989-2000年中国当代艺术实践的对话与叙 述》, 广州：岭南美术出版社, 2013年, 第79页。

16. 张培力和耿建翌于9月份被警方带去接受审讯，但当晚就被释放。基于笔者2017年7月31日，在杭州对张培力的专访。现 场横幅照片可见J. Noth, W. Pölhmann, K. Reschke 编: 《中国前卫艺术一一艺术与文化的反叛势力》, 牛津: 牛津大学 出版社, 1994年, 第36页。另可见戴汉志 (Hans Van Dijk) : 《文化大革命后的中国绘画: 风格发展和理论争论一一第2部 分：1979-1991》，《中国信息》，第6卷，第3期，1991-1992冬季，第15页。他将行动日期定为6月7日。

17.参见2011年12月31日的张培力访谈, 《有意识的工作：张培力》, 刘鼎、卢迎华、苏伟编: 《个体经验：1989-2000年中 国当代艺术实践的对话与叙述》, 广州: 岭南美术出版社, 2013年, 第79页。有趣的是, 把张培力的作品与汉密尔顿的标志性 拼贴画《是什么让今天的家变得如此不同，如此吸引人?》（1956年）放在一起考虑。

18. 这种比较不仅仅是隐喻性的: 王广义说, 张培力给了他一本《报头资料选》（其中典型的插图包括毛泽东、工人、士兵、农 民、民兵、农业耕作等。这是艺术家和业余爱好者在文革期间用来作为资料来源），这也是王的《大批判》系列之创作源泉。参 见李建亚编：王广义访谈《王广义: 沃霍尔的单纯比复杂更伟大》, 《新京报（网络版）》, 2013年10月9日。www.bjnews. com.cn/feature/2013/10/09/286413.html。2017年7月24日汶览。

19. 例如，栗宪庭曾赞赏《中国健美一一1989的风韵》（1989年）和《1989标准音》（1989年）, 可以在其中寻找中国的 "国家面孔”。参见栗宪庭: 《后89艺术中的无聊感和解构意识: “玩世现实主义” 和“政治波普”潮流析》 (初版1992年), Kela Shang译, 巫鸿、王必慈（Peggy Wang）编：《中国当代艺术：基本文献》，纽约：现代艺术博物馆, 2010年, 第165页。 
20. 基于笔者2017年7月31日, 在杭州对张培力的专访。

21. 王瑾: 《高雅文化热潮：邓小平时代中国的政治、美学与意识形态》，伯克利：加州大学出版社, 1996年。

22. 一位穿着比基尼的健美运动员出现在另一位浙江毕业生赵建人的艺术作品中《后者居上》（1988年）中。参见戴汉志 (Hans Van Dijk)：《文化大革命后的中国绘画：风格发展和理论争论一一第2部分：1979-1991》，《中国信息》，第6 卷, 第3期, 1991-1992冬季, 第10页。

23. Susan E. Brownell: 《体育》, Patrick Murphy编: 《中国流行文化手册》, 康涅狄格州: Greenwood Publishing Group, 1994年, 第127-128页。

24. 参见《中国对比基尼的恐惧》，《时代周刊》，1986年12月15日，第48页。此外，我还参考了1986年深圳电视台播放的 片段，网站 www.youtube.com/watch?v=Atx33YcgX24。2018年11月1日浏览。关于国内艺术家商业机会的出现，参见杜 柏贞 (Jane DeBevoise)：《国家与市场之间：后毛泽东时代的中国当代艺术》，莱顿：博点学术出版社, 2014年。

25. 张培力: 引自黄专: 《一个观念主义的反题: 论张培力》, 岳鸿飞、刘秀仪编: 《张培力: 确切的快感》, 香港: Blue Kingfisher出版社, 2011 年, 第25-26页。笔者在文中使用了自己的翻译, 另一已发表译文为《观念主义的对立面: 张培力》, 《典藏国际版》，第10卷，第6期，2011年11月/12月，第8-22页。

26. Susan Buck-Morss: 《看的辩证法: 瓦尔特·本雅明与拱廊项目》, 剑桥, 马萨诸塞: 麻省理工大学出版社, 1991年, 第 67页。张培力早期的萨克斯和爵士乐系列似乎也与爵士音乐的即兴与层次感有关。

27. 同上, 第222页。

28. 巫鸿: 《再论照片绘画》, Ackbar Abbas: 《陈丹青: 天安门之后的绘画》, 香港: 香港大学出版社, 1995年, 第10-13 页。

29. 均引自巫鸿《再论照片绘画》, 第11页。另附一则趣闻, 在一次开放工作室访问中, 以《为我们伟大祖国站岗》（1976

年) 而闻名的现实主义画家沈嘉蔚（现居澳大利亚）曾向笔者展示这幅画的草稿本，我记得里面有很多穿着制服的军人的黑白照 片, 用于绘画研究。

30. 彭丽君：《克隆的艺术：中国文化大革命期间的创作生产》，纽约：Verso出版社，2017年，第146页。以及林似竹 (Britta Erickson)：《生命的富足：中国当代艺术家刘小东影集1984-2006》，香港：Blue Kingfisher出版社，2008年。 在此感谢古婷婷提供的这两篇文章。另见巫鸿: 《“老照片热”与当代艺术》, 《聚焦: 摄影在中国》, 伦敦: Reaktion出版 社，2016年。见《红色照片潮与中国当代艺术》，巫鸿《放大：中国摄影史》（Reaktion, 2016）。

31. 张培力本人承认《中国健美一-1989年的风韵》（1989年）中的健美形象来自一本“体育杂志”，或许是1980年推出的 主要美容健康杂志《健与美》。基于笔者2017年7月31日, 在杭州对张培力的专访。

32. 同上。

33. 巫鸿在论及电视在中国当代艺术中的地位时, 曾详细讨论张培力的作品。巫鸿也深入地讨论到, 虽然中国艺术家在创作中涉 及到电视机，但他们并没有真正介入电视的系统，这仍是国家的特权。张培力的作品《水一一辞海标准版》（1991年），可以 说是最接近这个国家体制的部分。巫鸿: 《中国当代艺术中的电视》，《十月》，第125期, 2008年夏季, 第65-90页。

34.《张培力: 中国》, Galerie du Rond-Point, 1993年1月8日 - 3月7日。

35. 基于笔者2017年7月31日, 在杭州对张培力的专访。值得一提的是, 《作业一号》通常被认为是1992年的作品, 但张培力 说他1990年去北京进行后期制作。事实上, 正是此行, 并通过后期制作公司的关系, 他能够安排邢质斌拍摄《水一一辞海标准 版》（1991年）。

36. 另外, 《30 x 30》（1988年）也出现在三台显示器上, 尽管来自一个录像。关于每个作品的详细清单及尺寸和组成, 参 见《张培力》, 曾小军、艾未未、徐冰编: 《中国现代艺术内部流通材料/黑皮书》, 1994年, 私出版, 第72-75页。基于笔者 2017年7月31日, 在杭州对张培力的专访。

37. 在这些材料中, 张从中国带来了煤渣（制造煤砖的残渣），刷墙粉（用于粉刷墙壁）以及石灰。参见《张培力艺术工作手 册》第177-173页, 其中包括安装视图。基于笔者2017年7月31日, 在杭州对张培力的专访。 
38. 展览“张培力” , Galerie Crousel-Robelen [现更名为Galerie Chantal Crousel], 1993年5月29日 - 7月17日。见《艺 术工作手册》，第174-175页。张培力于1993年在意大利斯波莱托完成了一次现场安装，没有使用石膏，而是直接在地板上用 蜡片翻模。因缺乏时间和材料, 张培力的这两件蜡制作品都没有按原定计划完成。基于笔者2017年7月31日, 在杭州对张培力 的专访。

39. 姚嘉善 (Pauline Yao) : 《距离公式: 观者在张培力艺术中的互动》, 《张培力: 明确的乐趣》, 香港: Blue Kingfisher 出版社, 2011 年, 第35页。

40. 张培力花了 “很多年” 才完成《飞行器》, 这可能是因为必须将作品从他学校的工作室里搬出来。张培力说, 他原本打算着 力刻画直升机, 最后还是决定使用这种多涂层的方法。他还透露颜色也可能是一直变换着, 所以《张培力艺术工作手册》（第 185页）中画作可能是较早的版本，但除了颜色的浓度之外，我无法发现任何显着的差异。基于笔者于2017年7月31日，在杭州 对张培力的专访。

41. 作为媒体的象征, 张培力在 1987 年画了一台油印机。自1990年以来, 许多非官方出版物是由此机器印刷出版的, 其中包括 池社的声明，以及张培力的文字作品《艺术计划第二号》（1987年）。参见《张培力艺术工作手册》，第78-79页。顺便说一 句, 上面的油印画是一对文革时期的微笑着的新婚夫妇, 第二年, 张培力将这张照片带到了美国的Art OMI并绘于《红色婚礼》 (1992年) 中。

42. 虽然笔者没有问张培力, 但这也可能是当时军事意象的来源, 反之也是间接涉及 1989 年的北京军事行动的一种方式。徐 坦曾一直画广州鲜肉市场, 但从 1990年开始, 他转向坦克, 表面上是指向海湾战争, 参见《90年代一一无题之二》（19901991年）。J. Noth, W. Pölhmann, K. Reschke 编: 《中国前卫艺术一一艺术与文化的反叛势力》，牛津：牛津大学出版 社, 1994年, 第279页。

43. 基于笔者与康兰丝于2019年1月31日的私人对话。

44. 参见杜柏贞, 翁子健: 《1992年广州首届九十年代艺术双年展》, 《全球现代和当代艺术笔记》, 纽约现代艺术博物馆, 2015年4月21日, www.post.at.moma.org/content_items/590-the-1992-guangzhou-biennial-art-fair. 2018年11月22 日汶览。关于当时中国艺术市场的讨论，参见杜柏贞：《大生意，1990-93年》，《国家与市场之间：后毛泽东时代的中国当代 艺术》, 莱顿: 博睿学术出版社, 2014年。

45. 由于这些原因, 张培力简明地将1993年定为中国当代艺术的转折点; 参阅2010年9月11日至 11 月 21 日在REDCAT举办的 《不只是时间——张培力和朱加》展览手册中的《张培力与朱加之间的对话》, 洛杉矶, 2010年9月11日, www.redcat.org/ sites/redcat.org/files/gallery/linked-files/2011 06/NOT_BROCH_15A.pdf。2018年12月16日汶览。有关这些问题的 艺术史概述, 参阅王必慈 (Peggy Wang)：《新观众, 新能量：1993年创作的和展出的当代中国艺术》, 《全球现代和当代 艺术笔记》，纽约：现代艺术博物馆, 2015年8月19日, www.post.at.moma.org/content_items/612-new-audiences-newenergy-producing-and-exhibiting-contemporary-chinese-art-in-1993。2018年12月16日汶览。

46. 弗兰 (Francesca Dal Lago) : 《非不同寻常的艺术》, 岳鸿飞、刘秀仪编: 《张培力: 确切的快感》, 香港: Blue Kingfisher出版社, 2011 年, 第9页。

47. 张培力: 《与西方作战?》, 《中国: 15个工作室的近期创作》, 慕尼黑: Hahn Produktion, 1996年, 第133-135页。 张应策展人戴汉志（Hans van Dijk）的要求写下此文。此文的中文版首发于《江苏画刊》，1996年第6期，第18-19页; 同时 收于黄专与王景编: 《张培力艺术工作手册》, 第374-377页。

48. 1996年左右上海艺术家钱喂康离开艺术界, 其中有一部分原因是出于对机会主义的沮丧。他批评艺术家说: “我觉得艺术家 没意思，天天仰望纽约、伦敦，谈艺术动向、价格啊，新潮流怎么去双年展什么的，而从不去关注身边的世界。艺术家还说他们 是前卫的, 我开玩笑说, 中国有两种人说自己是前卫的, 一种人是共产党, 他们在党章里说, 自己是人民的先锋, 还有一种人就 是艺术家。”参见比利安娜 ·思瑞克 (Biljana Ciric) 对钱喂康访谈: 《上海滩 1979-2009: 上海艺术家个案》, 上海: 上海人 民美术出版社, 2010年, 第274页。

49. 参见小欧 (Orianna Cacchione) : 《相关节奏: 在全球化艺术世界中展现张培力与当代中国录像艺术》， 《当代中国艺术 杂志》, 2018年, 第5卷, 第1期, 第32-33页。 
This text is taken from Zhang Peili: From Painting to Video, edited by Olivier Krischer, published 2019 by ANU Press, The Australian National University, Canberra, Australia.

doi.org/10.22459/ZP.2019.05 